\title{
Analysis on Brand Development of Private Colleges and Universities in Guangdong-Hong Kong-Macao Greater Bay Area Based on the Perspective of Sustainable Development
}

\author{
Mingchao $\mathrm{Li}^{1, *}$ \\ ${ }^{1}$ Zhuhai College of Jilin University, Zhuhai, Guangdong, China \\ *Corresponding author. Email: 630808521@qq.com
}

\begin{abstract}
The special geographical location and political system of the Guangdong-Hong Kong-Macao Greater Bay Area and the international background of coexistence of multiple cultures have strong basic strengths and international advantages in education and talents, and have the rigid conditions for the development of education and talents gathering. The rapid development of the Guangdong-Hong Kong-Macao Greater Bay Area has brought rare opportunities and challenges to private higher education in Guangdong. This study analyzes the significance of private higher education for the development of the Bay Area from the perspective of sustainable development theory, and proposes corresponding strategies for high-quality development.
\end{abstract}

\section{Keywords: sustainable development theory, Guangdong-Hong Kong-Macao Greater Bay Area, private}

colleges and universities

\section{INTRODUCTION}

With the pace of China's reform and opening up, China's private education has gradually developed and expanded. The total number of schools and the number of students in the private education system has reached a considerable scale, and has played a huge role in promoting the development of China's education. [1]. Chinese private colleges and universities have played an active role in promoting the popularization of higher education, enriching the curriculum system of higher education, and increasing the diversity of higher education. They are important forms of support for

*Project: The research project of the "Thirteenth Five-Year Plan" of Party Construction in Guangdong Educational Science in 2019, "Research on Party Construction in Universities Leads Higher Education's 'Enhancing Supplying Strengthening' Plan — Exploration of Brand Building in Independent Colleges and Universities in New Era," Project No.: 2019JKDJ001; Research Project of the Party Construction Research Association of Higher Education Institutions in Guangdong Province "Research on the Party Building Leading Strategy for Brand Development of Private Colleges and Universities" in 2019, Project No.: 2019MB038; Research Project of Private Education Research Base of Zhuhai College of Jilin University "Study on Strategies for Improving the Running Level of Private Universities from the Perspective of Sustainable Development Theory"; 2019 Key Project of Party Construction and Ideological and Political Education Research of Zhuhai College of Jilin University" Party Construction Leading Independent College Brand Development Strategy ", Project No.: 2019JZDJ001.
China's higher education industry. However, for private colleges and universities, the problems of survival and development are still the main problems they are facing with, especially in the context of the great new era of economic development in the Pearl River Delta, which poses new challenges to the development of private colleges and universities in the Guangdong-Hong Kong-Macao Greater Bay Area. The research on sustainable development of colleges and universities has scientific theoretical guiding significance for the comprehensive improvement of the dynamic capabilities of colleges and universities. Therefore, this research will analyze the development of private universities in Guangdong-Hong Kong-Macao Greater Bay Area based on the theory of sustainable development and propose corresponding countermeasures.

Relevant surveys show that China's higher education popularization level will furtherly increase in 2020 , and the overall gross enrollment rate of private universities will reach the goal of $40 \%$. In the next few years, as higher education enters the stage of rapid development of mass education, the number of higher education institutions may increase simultaneously. Most private colleges and universities aim at cultivating application-oriented talents. In terms of subject setting, they are dynamically adjusted according to industry and industry trends, and they focus on practical internships 
in curriculum design. Usually, they use the productioneducation integration model to cultivate students' practical working ability. And private colleges and universities are most likely to enjoy the market dividend of overflowing demand for applied talents. According to relevant estimates, it is estimated that the market penetration rate of private higher education in China will increase from $21.9 \%$ to $24.3 \%$ from 2016 to 2021, and the number of private colleges and universities in 2021 will reach 8 million, with a compound annual growth rate of $4.9 \%$ of five years.

The Guangdong-Hong Kong-Macao Greater Bay Area was established as the China's key development strategy at the "two sessions" in 2017. In particular, the "Guangdong-Hong Kong-Macao Greater Bay Area Development Plan Outline" was officially released on February 18, 2019 with the consent of the Party Central Committee and the State Council. It made comprehensive planning for the strategic positioning, development goals, and spatial layout of the Guangdong-Hong Kong-Macao Greater Bay Area. Its own broad prospects and its role in promoting economic and private education institutions have attracted much attention. In the context of the great economic era, Chinese private colleges and universities have important responsibilities to undertake applied personnel training and economic and social services. Facing many challenges in the construction of the Guangdong-Hong Kong-Macao Greater Bay Area, it is also a period of strategic opportunity. Therefore, in the context of the construction of the Guangdong-Hong Kong-Macao Greater Bay Area, it is very important of many issues such as how can private colleges and universities in Guangdong explore and reform their development roads on the basis of summing up their past development experience, how to better cope with the rapid economic development in the GuangdongHong Kong-Macao Greater Bay Area, and how to seize the favorable conditions under the new economic normal to carry out its own reforms and innovations.

\section{ECONOMIC DEVELOPMENT OF GuANGDONG-HoNg KONG-MACAO GREATER BAY AREA}

As an important form, the Bay Area economy has become a major growth pole that drives global economic development and a leader in leading major technological changes. Internationally-developed Bay Areas have made outstanding contributions to the development of the local economy and the world economy. The Guangdong-Hong Kong-Macao Greater Bay Area is composed of nine prefecture-level cities in the Hong Kong Special Administrative Region, Macau Special Administrative Region and the Pearl River Delta, with an area of about 56,000 square kilometers and a population of 66 million. Guangdong, Hong
Kong, and Macao, from the perspective of natural geographical conditions and from the perspective of human history, are of the same origin, connected and inseparable. However, due to the drastic changes in the global political and economic patterns, major historical changes have taken place in the human, social, spatial, and values of the three places. With the return of Hong Kong and Macau, the three places seem to have returned to the starting point of history, but under the framework of the "one country, two systems", the cooperative development of Guangdong, Hong Kong, and Macao is still just staying at the surface. Therefore, integrating Guangdong, Hong Kong, and Macau resources to build a platform for the in-depth development of Guangdong, Hong Kong, and Macau has become a hotspot of common concern from all walks of life. The Guangdong-Hong Kong-Macao Greater Bay Area has developed into a national strategy, and its establishment background is global economic integration. The establishment of the Guangdong-Hong Kong-Macao Greater Bay Area is not only the need for Guangdong Province to continue deepening reforms, but also the requirements for sustainable development of Hong Kong and Macau, and is also an important part of China's implementation of major strategies. In March 2018, at the first meeting of the 13th National People's Congress, General Secretary $\mathrm{Xi}$ Jinping pointed out that it is necessary to seize the opportunity of economic construction of the Guangdong-Hong Kong-Macao Greater Bay Area and build a world-class Bay Area and world-class city cluster.

The economic foundation determines the superstructure [2]. The economic development of the Guangdong-Hong Kong-Macao Greater Bay Area is the basis for the development of regional private education. The strategic positioning of the Guangdong-Hong Kong-Macao Greater Bay Area also determines the positioning and development direction of regional private education development. The Guangdong-Hong Kong-Macao Greater Bay Area has many inherent advantages and foundations. Based on this, in the future, it will gradually build a technological innovation highland, a financial service highland, an advanced manufacturing center, a modern service industry center, an international logistics center, an international economic and trade center, and a high-quality living circle. The development objective of the "GuangdongHong Kong-Macao Greater Bay Area Development Planning Outline" is to increase the comprehensive strength of the Guangdong-Hong Kong-Macao Greater Bay Area significantly by 2022, further deepen and broaden the cooperation between Guangdong, Hong Kong, and Macao, further increase the endogenous development momentum of the region. The development of a world-class Bay Area and a world urban agglomeration framework has basically taken 
shape with vigorous development, outstanding innovation capabilities, optimized industrial structure, smooth flow of elements, and beautiful ecological environment.

\section{OPPORTUNITIES AND CHALLENGES OF GUANGDONG'S PRIVATE EDUCATION UNDER THE ECONOMIC CONSTRUCTION OF THE GUANGDONG-HONG KONG-MACAO GREATER BAY AREA}

A. Opportunities and challenges of Guangdong private education under the economic construction of the Guangdong-Hong Kong-Macao Greater Bay Area

By 2035, the ambitious goals of the GuangdongHong Kong-Macao Greater Bay Area International First-Class Bay Area will be fully realized, which in particular will bring great opportunities to Guangdong's private education. The development of regional socioeconomics has driven the development of private education. At the same time, the region must rely on private colleges and universities to provide high-quality talents for its social and economic development. The economic construction of the Guangdong-Hong KongMacao Greater Bay Area is mainly to explore and develop innovative roads. This requires a lot of highly qualified personnel to contribute to its development. In this regard, the economic construction of the Guangdong-Hong Kong-Macao Greater Bay Area provides a huge opportunity for the development of private education in China. Talent is a key factor in the development of the region, and the main source of talent is higher education. Therefore, based on the huge demand for economic construction in the GuangdongHong Kong-Macao Greater Bay Area, Guangdong's private education needs to establish a firm spirit of "striving for first-rate, making up for shortcomings, and strengthening characteristics", so that it can make itself swift and strong to seize the favorable opportunity of this transformation and reform, closely follow the relevant national policies, combined with the specific needs of talents for the economic construction of the Guangdong-Hong Kong-Macao Greater Bay Area, and complete their own development and transformation with high quality. This will not only provide a steady stream of talents and uninterrupted vitality for the economic construction of the Guangdong-Hong KongMacao Greater Bay Area, but also make the comprehensive ability of Guangdong colleges and universities reach a new level, and greatly enhance the influence and motivation of the colleges and universities in the overall private colleges and universities.

However, it is also necessary to see the challenges of Guangdong's private education under the economic construction of the Guangdong-Hong Kong-Macao
Greater Bay Area. At present, Guangdong's private colleges are disconnected from social needs, the number of students is insufficient, the impact of the new education model, and the standardization of private colleges. These heavy practical obstacles are pressing like a boulder to private colleges and universities, and have brought huge challenges to the transformation and development of private education.

\section{B. The important role of private education in the development of the Guangdong-Hong Kong-Macao Greater Bay Area}

The development of the Guangdong-Hong KongMacao Greater Bay Area needs to overcome many difficulties and break many bottlenecks. There is no doubt that education is an important means of achieving this goal. High-quality private education has at least the following important roles in the rapid development of the Guangdong-Hong Kong-Macao Greater Bay Area:

1) Cultivating awareness of the Bay Area: The New York Bay Area, the San Francisco Bay Area, and the Tokyo Bay Area have a long history of development and occupy an important place in international trade. If the Guangdong-Hong Kong-Macao Greater Bay Area wants to achieve latecomers' overtaking and "Bay" road overtaking, it must focus on training Bay Area awareness, that is, the awareness of innovation, cooperation, and humanity, and education is an important way to cultivate the awareness of the Bay Area. First, education is the foundation of innovation, and innovation runs through all aspects of teaching and learning. Secondly, education itself is the product of cooperation, and students' sense of cooperation can effectively improve the effectiveness of education. Third, education has a responsibility to call for humanity. The core of humanistic consciousness is to respect human values, respect for human independence, promote human ideals, and develop human undertakings. With the development of human civilization, humanistic consciousness has been endowed with many new era connotations. Furthermore, the important role of education in cultivating awareness of the Bay Area is also reflected in its preventive and corrective effects. Education can to some extent correct the negative factors of family education and prevent the adverse effects of social education to a certain extent

2) Transporting talents to the Bay Area: The rapid development of the New York Bay Area, the San Francisco Bay Area, and the Tokyo Bay Area are inseparable from the gathering and training of outstanding talents. According to the theory of human capital, education has played a huge role in promoting 
economic development [3]. First, education bears the heavy responsibility of cultivating talents at all levels for the Guangdong-Hong Kong-Macao Greater Bay Area. Talent is the first production factor for the development of the Guangdong-Hong Kong-Macao Greater Bay Area, while education is an important way to produce talent. Second, education is responsible for optimizing talents. The development of science and technology changes with each passing day, and the demand for talents changes from time to time. Education and training bear the responsibility of optimizing talents. Third, education reform is an important breakthrough to promote the reform of scientific research industrialization. Scientific research institutes and business units are two levels of scientific research industrialization reform, and also a breakthrough that the Guangdong-Hong Kong-Macao Greater Bay Area urgently needs to open. Therefore, education reform will definitely promote the reform of scientific research industrialization and will also help the development of Guangdong-Hong Kong-Macao Greater Bay Area. In addition, it is best that the talents cultivated by education are moderately forwardlooking. This places higher requirements on the training objectives of education, which is also the direction of education reform.

3) Optimizing the environment in the Bay Area: Education is a key issue of people's livelihood. The excellent educational environment of the GuangdongHong Kong-Macao Greater Bay Area is conducive to attracting overseas talents to start businesses, stabilize the education of children of builders, and promote fair education. It can be said that education is a green engine for the development of the Guangdong-Hong Kong-Macao Greater Bay Area. The excellent educational environment of the Guangdong-Hong Kong-Macao Greater Bay Area is conducive to attracting overseas talents to start businesses and build a multi-level talent system.

4) Stimulating the economy of the Bay Area: Education is not only a cause of people's livelihood that benefits the country and the people, but also a green industry that stimulates economic growth. In recent years, the state's support of the education industry has opened up channels for education consumption, and education consumption has become one of the important forces that drives Chinese demand. If the hot spot of education consumption is released, it will release huge market potential.

\section{CHINA'S PRIVATE HIGHER EDUCATION FROM THE PERSPECTIVE OF SUSTAINABLE DEVELOPMENT}

About the sustainable development theory, the United Nations convened a conference on the human environment in Stockholm, Sweden in 1972. The conference was the first major international discussion on sustainable development theory and created the term "eco-development". The meeting adopted the "United Nations Declaration on the Human Environment", linked environmental issues and development for the first time, and pointed out that developed countries and developing countries have shared responsibility for environmental resources. In 1983, the United Nations established the World Commission on Environment and Development to study the relationship between economic growth and environmental degradation. In 1987, the Commission first introduced the concept of "sustainable development" into the formal political arena, and defined "sustainable development" as "satisfying the contemporary human needs without compromising the development of future generations' ability to meet needs" in "Our Common Future". For the first time, "Agenda 21" issued by the United Nations in 1990 pushed the issue of sustainable development from a theoretical level to action [4] [5]. Sustainable development is a huge social change and innovation. In the report of the Nineteenth National Congress of the Communist Party of China, the strategy of sustainable development, the strategy of rejuvenating the country through science and education, the strategy of strengthening the country by talents, the strategy of driving development through innovation, the strategy of revitalizing the countryside, the strategy of regional coordinated development, and the strategy of militarycivilian integration are listed as strategies for the decisive period in the comprehensive construction of a well-off society.

Sustainable development mainly refers to a way of development based on the sustainable use of resources and the balance of the ecological environment, the premise of sustainable economic development, and the pursuit of comprehensive social progress and the coordinated development of economic society, population, resources and the environment. The main body of sustainable development is human society, which contains all-round sustainable development of various social subsystems in the fields of economy, ecology, science and technology, education and so on. Economy is the foundation and conditions for sustainable development; ecology is the prerequisite and guarantee for sustainable development; technology is the key to sustainable development; education is the core driving force of sustainable development [6].

The sustainable development of education means that education is the fundamental plan for sustainable 
economic, social and natural development based on people. About the sustainable development of higher education: higher education is a typical manifestation of the special phenomenon of educational society. Education is the basic and pioneering project of a national development strategy, and higher education is the most closely linked part of education to economic and social development. The sustainable development of higher education is an important part of the national implementation of sustainable development strategies. This article is based on the concept of sustainable development. As for the meaning of sustainable development of private colleges and universities in the academic world, because of different research areas and starting points, the scope of the definition is wide or narrow, and the difference is more obvious. The sustainable development of private colleges and universities refers to the introduction of the concept and principles of sustainable development into the field of colleges and universities [7]. As an important part of the development of higher education system, private colleges and universities must respect and coordinate with the development of society, politics, economy, science and technology, and culture, as well as the coordinated development of their own quantity, quality, structure, and efficiency. The sustainable development of private colleges and universities is to introduce the theory and concepts of sustainable development into the development of private colleges and universities, to explore a new model for the survival and development of private colleges and universities, to point out that the development of private colleges and universities must not only follow the coordinated development of its own quantity, quality, structure, and benefits, and to form a scientific internal operating mechanism. At the same time, it is also necessary to respect the coordinated development with society, politics, economy, science and technology, and culture to form a good external environment [8]. Some scholars have pointed out that the sustainable development of private colleges and universities means that private colleges and universities follow their own development rules, with comprehensive and coordinated development of quality, scale, structure, and benefits, human, financial, and physical resources are coordinated with each other, and the three major functions of talent cultivation, scientific research, and social services are effectively realized, achieving a state of positive interaction between the scientific development of private universities and the development of economic and social sciences [9]. This study believes that the sustainable development of private colleges and universities means that private colleges and universities follow the principles of comprehensiveness, coordination, efficiency, and sustainability of their own development, and use internal and external resources to improve their quality, scale, structure, and benefits, so that they can coordinate develop and realize the responsibility mission of personnel training, scientific research, social services and cultural heritage, and then achieve the healthy development of private education to meet the needs of diverse education and the needs of economic and social development.

\section{ESTABLISHING STRATEGIES FOR ENHANCING THE SUSTAINABLE DEVELOPMENT ABILITY OF PRIVATE UNDERGRADUATE COLLEGES AND UNIVERSITIES IN THE GUANGDONG-HoNg KONG-MACAO GREATER BAY AREA}

The sustainable development of private colleges and universities is a systematic project that involves national policies, laws and regulations, investment funds, the number of students, the quality of students, and the quality of teachers. Therefore, the sustainable development of private colleges and universities requires the support of national policies, financial support from investors, and the level of teachers' teaching and abilities, so that private colleges and universities can achieve comprehensive, coordinated, efficient, and long-term development.

\section{A. Improving the mechanism: increasing the importance of party building in private colleges and universities}

General Secretary Xi clearly stated in the report of the 19th National Congress of the Chinese Communist Party: "The political construction of the party is the fundamental construction of the party and determines the direction and role of party construction. Ensuring that the entire party submits to the central government, upholding the party's central authority, and centralizing and unifying leadership are the primary tasks of the party's political construction." In China's higher education system, private colleges and universities are an important supplement to public colleges and universities. Like public colleges and universities, it is a must to adhere to the direction of socialist schooling. Therefore, the party building work of private colleges and universities must not only meet the requirements of the development of the new era, but also meet the requirements of socialist development. When carrying out party building work, private colleges and universities must adhere to and implement the party's guidelines, practice the party's line, and carefully study $\mathrm{Xi}$ Jinping's thought of socialism with Chinese characteristics in the new era.

Strengthening party building is the need for private colleges and universities to achieve sustainable development. If private colleges and universities want to promote their sustainable development, they also need to strengthen party building. Specifically, private colleges and universities face great competition 
pressure, and various factors appearing in the process of running a school will have a certain impact on the school's own development [10]. Therefore, only with the help of perfect party building can they lead private colleges and universities to develop in the right direction. Second, private colleges and universities want to maintain a good development environment at all times, and strengthening party building is also an effective way to achieve this goal. As far as China's existing education system is concerned, it can be seen as a direct reflection of Chinese party's management and macro guidance of the current educational environment. Therefore, the party's guidance to private universities is also an important link. Therefore, strengthening party building work in private colleges and universities must be supported by strong party building work.

\section{B. Being Brand-driven: implementation of brand marketing strategy of private colleges and universities}

With the diversified demand for higher education products, the independent legalization of colleges and universities, the change in government investment structure, the diversification of investment subjects, the diversification of higher education forms and levels, and the acceleration of the global economic integration process, competition among universities in funding, student resources, high-level teachers, scientific research projects, subject development, scale, ranking, student employment, and social services is becoming increasingly fierce. Creating a school brand has become an inevitable phenomenon in China's social transformation [11]. As the higher education market enters the "competitive era", establishing brand awareness, creating and owning brands, enhancing its strength in future competition, and building a university brand with core competitiveness have become one of the key ways for private universities to improve their competitiveness.

The brand of colleges and universities is shaped on the basis of the inherent advantages formed by colleges and universities in the long-term development process and the channels of obtaining external resources. Therefore, in order to build a university brand in private colleges and universities, it is necessary to build it step by step from the inside and outside of the university. Specifically, it is necessary to position university brands based on the characteristics of running a school, to cultivate internal brands as the main content of university branding, to pay close attention to the experience and satisfaction of stakeholders, to integrate university brand marketing and communication, and to actively carry out the branding organization and management. The branding of private colleges and universities is a very systematic construction project, which must be guided by systematic and scientific theories and methods.

\section{Simultaneous introduction and cultivation: building a stable teaching staff to improve the quality of education and teaching}

Private colleges and universities should attach great importance to the construction of teaching staff. Guangdong-Hong Kong-Macao Greater Bay Area private colleges and universities can take advantage of the Bay Area's regional advantages and their own advantages to adopt a variety of mechanisms, such as cooperative schooling, combining external introduction and internal training, combining full-time and part-time employment, optimizing the structure of the teaching staff, and improving teachers' education and teaching level and ability to build a high-quality, high-level teaching team. It can also construct a dual-teaching teaching team and improve the professional quality and ability of teachers. With the development of private universities, the teaching of laboratory construction, the use of teaching equipment and software, and the improvement of office conditions have become increasingly demanding. Colleges and universities must pay attention to the improvement of teachers' office and living conditions.

\section{Deepening reform: focusing on discipline construction and professional characteristics}

First, with teaching reform as the starting point, teachers are encouraged to reform the teaching content, teaching methods, and teaching methods to improve the quality of education and teaching. It is important to encourage teachers to carry out teaching and research reforms to improve teachers' scientific research level while improving their teaching ability. Secondly, in the process of formulating the talent training plan, when setting the curriculum, it is a necessity to pay attention to the interdisciplinary and comprehensive nature between disciplines and specialties, and highlight the characteristics of the college curriculum. In terms of professional application and curriculum setting, it is also necessary to pay attention to social research, highly integrate new economic growth points in the adjustment of the industrial structure of the Greater Bay Area, pay attention to the scientificity, rationality, and foresight of discipline construction, and formulate specialties that meet the needs of long-term social development and talent development programs. Finally, under the conditions of maturity, colleges and universities must condense their characteristics and focus on the development of disciplines and majors, thereby increasing their popularity. In terms of specialty setting, it will be necessary to take advantage of the advantages of private colleges and universities to cultivate application-oriented talents required for the construction of the Bay Area. 


\section{E. Changing the concept: optimizing the development environment of private colleges and universities}

It is necessary to correctly guide the public's scientific cognition of private colleges and universities to make them realize that private colleges and universities are an important part of China's higher education and play an increasingly important role in China's higher education. Furthermore, it is important to ideologically recognize that the role of private colleges and universities in personnel training, social services, and economic development cannot be ignored. Private colleges and universities can condense the characteristics of running a school, build their own advantages, and increase their reputation through quality engineering projects such as brand specialty, specialty specialty, and key discipline construction. To a certain extent, the government must change its concept and provide a loose development environment for the development of private colleges and universities. It can provide a certain social security system in terms of capital investment and use, the number and quality of students, employment rate and employment conditions, and provide momentum for the sustainable development of private colleges.

\section{CONCLUSION}

The economic construction of the Guangdong-Hong Kong-Macao Greater Bay Area is both an opportunity and a huge challenge for private colleges and universities, especially for Guangdong colleges and universities, especially private colleges and universities in the Greater Bay Area. With the further development of the politics and economy of the Guangdong-Hong Kong-Macao Greater Bay Area and the continuous progress of private education in the region, opportunities and challenges should be seized in the specific development process. According to the status quo of economic and social development and in combination with relevant Bay Area enterprises and industries' standards for talent demand, there should be outstanding and focused talent training programs to meet the social demand for talent. At the same time, schools should improve the overall education and teaching level of teachers and their social influence, and be invincible in the context of rapid development of economic construction.

\section{References}

[1] Xie Liuzhi, On the Innovation of Ideological and Political Work in Private Colleges and Universities in the Era of Big Data [J]. Modern Business Trade Industry, 2019, 40(15): 143-145. (in Chinese)

[2] Karl Marx, Karl Marx Frederick Engels Collected Works Vol. 3 [M]. Beijing, People's Publishing House, 2010: 41. (in Chinese)

[3] Theodore Schultz Economic Growth and Agriculture [M] Beijing: China Renmin University Press, 2015. (in Chinese)
[4] Levidow, L. (2014) What is Green Economy? Diverse agendas, their tensions and potential futures. IKD, Open University.

[5] Perez-Carmona, A. (2011) Growth: A Discussion of the Margins of Economic and Ecological Thought in Meuleman, L. (eds.) (2011) Transgovernance Advancing Sustainability Governance, Belgium.

[6] Report on the "Research of the School-run System and Development Policy of Private Colleges and Universities" [J]. University (Academic), 2018 (11): 79-87+78. (in Chinese)

[7] Qi Yongjuan, Research on Private Higher Education Development [D]. Shijiazhuang, Hebei Normal University, 2010. (in Chinese)

[8] Lv Jing, An Analysis of the Problems and Paths in the Sustainable Development of Private Colleges and Universities in China [D]. Soochow: Soochow University, 2015. (in Chinese)

[9] Huang Jian, Evaluation of Sustainable Development of Private Colleges: Based on Colleges in Jiangxi [J]. Education Research Monthly, 2014(7). (in Chinese)

[10] Wu Qian, An Enlightenment to Ideological and Political Education Engels's Development of Socialism from Utopian to Science $[\mathrm{J}]$. Teaching and Research, 2016(6): 66-70. (in Chinese)

[11] Li Shiding, Winning Through Integration: Sharp Weapons for Building Strong Brands $[\mathrm{M}]$. Guangzhou, Guangdong Economic Press, 2001: 90. (in Chinese) 